\title{
Prediction and validation of flow-dependent uptake of ammonium over a seagrass-hardbottom community in Florida Bay
}

\author{
Christopher D. Cornelisen ${ }^{1,3}$, Florence I. M. Thomas ${ }^{2, *}$ \\ ${ }^{1}$ Department of Biology, University of South Florida, Tampa, Florida 33620, USA \\ ${ }^{2}$ Hawaii Institute of Marine Biology, University of Hawaii Manoa, Honolulu, Hawaii 96744, USA \\ ${ }^{3}$ Present address: Cawthron Institute, 98 Halifax St East, Nelson 7042, New Zealand
}

\begin{abstract}
Hydrodynamic surveys and field flume experiments were carried out to characterize water flow and measure nutrient uptake over a shallow hardbottom flat sparsely colonized by seagrasses, a complex community type commonly found along corridors linking Florida Bay and the Florida reef tract. Acoustic Doppler velocimeter profiles collected in tide-driven flows revealed benthic hydrodynamic conditions indicative of disturbed boundary layer flow; attenuation of flow near the benthos and measures of bottom friction were considerably less than observed in densely colonized seagrass beds. Mass-transfer coefficients $(S)$ for ammonium, predicted using velocity data and estimates of bottom friction, ranged between $0.35 \times 10^{4}$ and $1.91 \times 10^{4} \mathrm{~m} \mathrm{~s}^{-1}$ for current velocity between 0.03 and $0.39 \mathrm{~m} \mathrm{~s}^{-1}$. Values of $S$ measured using a field flume were within the same range as predicted values, validating that ammonium uptake by the community is occurring near the masstransfer limit. Mass-transfer coefficients fell slightly above those previously measured for low-relief coral rubble and below those for dense seagrass canopies, thereby confirming a close link between bottom roughness and mass transfer. Predicted ammonium uptake based on ambient velocity and nutrient concentrations varied considerably over the tidal cycle (range $=0.014$ to $0.094 \mu \mathrm{mol} \mathrm{NH_{4 }} \mathrm{m}^{-2}$ $\mathrm{s}^{-1}$ ) and highlighted the importance of temporal variation in both current velocity and nutrient concentration in driving rates of nutrient uptake. Additional field flume experiments using ${ }^{15} \mathrm{~N}$-labeled ammonium enabled us to examine flow-dependent uptake for a number of organisms within the complex community. Uptake rates were found to vary among seagrasses, macroalgae, and finger corals, perhaps due to physiological or morphological differences or varying locations within the canopy.
\end{abstract}

KEY WORDS: Nutrient uptake - Water flow · Mass-transfer limitation - Seagrass · Hardbottom · ${ }^{15} \mathrm{~N}$ uptake $\cdot$ Isotope label Resale or republication not permitted without written consent of the publisher

\section{INTRODUCTION}

There is an extensive database on the effects of water flow and bottom roughness on the exchange of chemicals between benthic surfaces and the water column (e.g. Boudreau \& Scott 1978, Riber \& Wetzel 1987 , Jorgensen \& Des Marais 1990). A significant portion of this literature has investigated the effects of water flow on mass transfer in coral reefs (Bilger \& Atkinson 1992, Thomas \& Atkinson 1997, Hearn et al. 2001, Falter et al. 2004) and seagrass beds (Thomas et al. 2000, Thomas \& Cornelisen 2003, Morris et al. 2008). These studies demonstrated that rates of nutrient uptake for these communities were controlled by the rate of nutrient flux to uptake surfaces (i.e. were mass-transfer limited). When uptake is mass-transfer limited, nutrient uptake by the benthos is dependent on factors that affect the rate of mass transfer, including velocity and roughness of the benthic assemblage, diffusivity and concentration of the nutrient, and fluid viscosity.

Due to the evidence suggesting that nutrient uptake is mass-transfer limited in many benthic systems, semiempirical heat and mass-transfer models (see Bilger \& Atkinson 1992, Falter et al. 2004) and models based on 
energy dissipation in the water column (Hearn et al. 2001) have been used to predict rates of nutrient uptake. Estimates of uptake coefficients predicted from these models are in close agreement with those directly measured in flume experiments (Baird \& Atkinson 1997, Thomas \& Atkinson 1997, Thomas et al. 2000, Atkinson et al. 2001, Falter et al. 2004). Thus there is potential to use hydrodynamic and nutrient data collected in the field to estimate nutrient uptake by benthic communities under natural environmental conditions that vary in both time and space. A recent example of such applications was demonstrated by Baird et al. (2004), who compared predictions with measured values based on 'upstream-downstream' nutrient concentrations over coral reef flats. Studies such as these are necessary for understanding links between physical and biological processes and the consequence such interactions have on the fate of nutrients within nearshore environments, which may be particularly important with increasing anthropogenic nutrient loading and changes in benthic composition.

Extensive areas of mixed seagrass-hardbottom habitat along the Florida Keys provide an excellent opportunity to apply the approaches developed in previous work to predict uptake rates for nutrients in complex multi-species assemblages if nutrient uptake is shown to be mass-transfer limited. The community studied here is composed of a patchy mixture of sparsely distributed seagrasses, non-reef-building corals, and macroalgae, and is a common bottom type situated along major corridors for water exchange between the western portion of Florida Bay and the reef tract. The benthos is exposed to strong tidal flows so that the flow is predominantly unidirectional with changing nutrient conditions that coincide with tidal fluctuations; hence the area is ideal for investigating the potential interactive effects of current velocity and nutrient concentration on nutrient uptake.

In the present study we characterized hydrodynamic regime over a range of current velocity using an acoustic Doppler velocimeter and use the velocity data to predict mass transfer rates for the community. We then measured mass-transfer coefficients $(S)$ over a range of simulated current velocity in a field portable flume (see Cornelisen \& Thomas 2004) and compared measured values to those predicted from mass-transfer theory (see Bilger \& Atkinson 1992, Thomas et al. 2000) to validate whether ammonium uptake by the community is mass-transfer limited. Following validation, we combined mass-transfer coefficients with measures of ambient current velocity and nutrient concentrations over a tidal cycle to examine the range of nutrient uptake likely occurring under varying environmental conditions in Florida Bay.
The mixed seagrass-hardbottom community represents an ideal model system to examine the correlation between bottom roughness and nutrient uptake. If the community is mass-transfer limited, it is hypothesized that values of $S$ will lie along a continuum according to bottom roughness; e.g. values would lie above those for benthic surfaces dominated by low-relief coral rubble (Thomas \& Atkinson 1997) and below those for densely populated seagrass canopies (Thomas et al. 2000). We also conducted field flume experiments using isotopically labeled ammonium $\left({ }^{15} \mathrm{NH}_{4}^{+}\right)$in order to measure uptake rates for a number of benthic organisms (seagrasses, macroalgae, corals) that form these complex communities, and we validated that uptake occurred in the benthos. This approach provides a unique opportunity to investigate the effect of hydrodynamic regime on a range of organisms that vary in physiology, morphology, and position within the canopy.

\section{MATERIALS AND METHODS}

Study site. The study site was Old Sweat Bank $\left(24^{\circ} 49^{\prime} 03^{\prime \prime} \mathrm{N}, 80^{\circ} 52^{\prime} 04^{\prime \prime} \mathrm{W}\right)$, which is located in Long Key Channel on the Florida Bay side of the Keys, $\sim 2 \mathrm{~km}$ northwest of US Highway 1 (Fig. 1). Benthic communities in the waters surrounding the Florida Keys include coral reefs, seagrass beds, hardbottom, and areas of bare sediment. Seagrass beds are most dominant and comprise $\sim 70 \%$ of the area within the Florida Keys National Marine Sanctuary (FMRI 1998). A portion of this habitat includes shallow $(\sim 0.5$ to $2 \mathrm{~m}$ depth) carbonate banks, such as Old Sweat Bank, that are composed of seagrasses (Thalassia testudinum and Syringodium filiforme) sparsely to intermediately mixed with hardbottom organisms, including ahermatypic corals (e.g. Porites spp., Manicina areolata), calcareous algae (e.g. Penicillus spp., Halimeda spp., Rhipocephalus spp.), and sponges (e.g. Chondrilla nucula, Tedania ignis) (Fig. 1). Old Sweat Bank lies along a major corridor for water exchange (Long Key Channel) between Florida Bay and the Atlantic Ocean and is exposed to semi-diurnal tides that impose a large range of current velocity $\left(\sim 0.05\right.$ to $0.50 \mathrm{~m} \mathrm{~s}^{-1}$; Wang 1998).

Hydrodynamic characterization. Hydrodynamic data were collected at 4 sites spaced $\sim 100 \mathrm{~m}$ apart between 11 and 15 September 2000. For comparison purposes, data were also collected in a nearby uniform patch of dense seagrass. Five to 7 velocity profiles were collected at each site using an acoustic Doppler velocimeter (10 Hz Field ADV, YSI/Sontek) that measures the velocity of particles in 3 dimensions: longitudinal along the main flow $(U)$, transverse $(V)$, and ver- 
Fig. 1. (a) Location of Old Sweat Bank in Long Key Channel relative to Florida Bay and the Florida reef tract. Arrows indicate major corridors for water exchange between Florida Bay and the Atlantic. (b) Densities of dominant benthic organisms found at the study site. A shoot, thallus, or colony represented an 'individual' for seagrass, macroalgae, and coral, respectively. Corals included Porites spp., Cladocora arbuscula, and Manicina areolata, and sponges were primarily Chondrilla nucula and Tedania ignis. Data are based on organism abundances recorded in a total of 44 quadrats $\left(0.0625 \mathrm{~m}^{2}\right)$ placed among the 4 sampling sites. Error bars: +1 SD

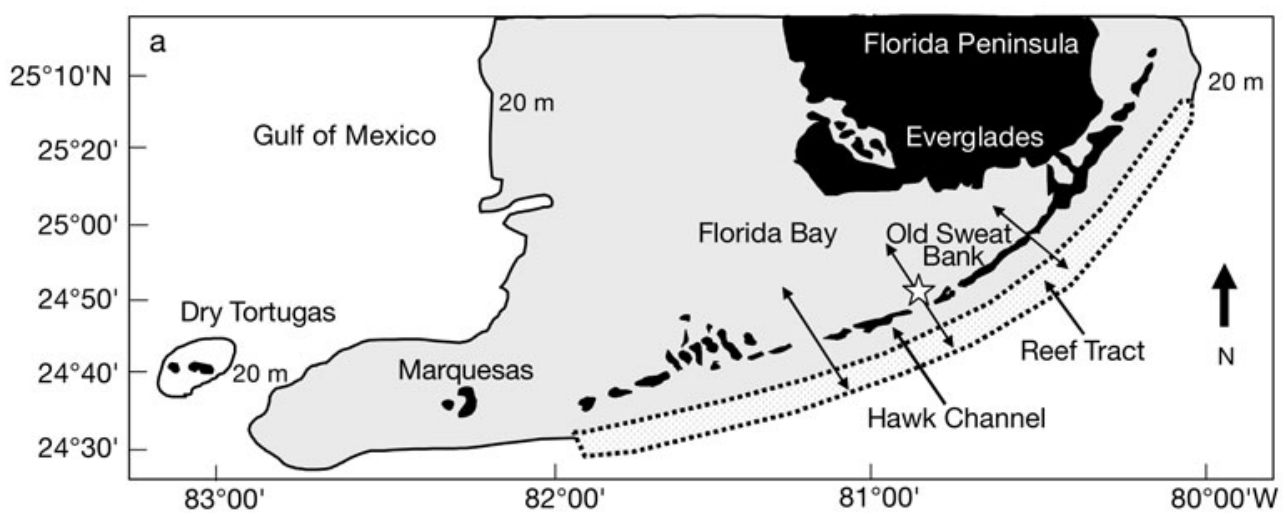

b

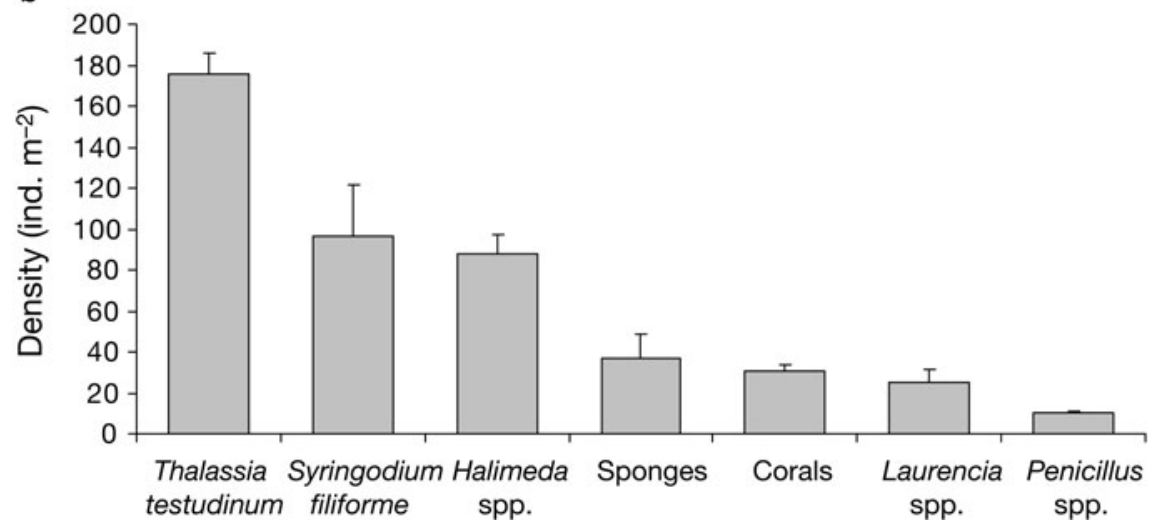

tical $(W)$. The sensor was fixed to a movable arm that extended $\sim 0.4 \mathrm{~m}$ from a vertical pole attached to a flat weighted base, which allowed the sensor to be fixed at various heights above the bottom and prevented any movement of the probe during measurements. During each profile, the depth of the water and the height of roughness elements including seagrass leaves and hardbottom organisms (e.g. macroalgae, corals) were recorded.

For each profile, velocity data were recorded at $10 \mathrm{~Hz}$ for 1 to $2 \mathrm{~min}$ at each of 9 to 12 heights above the sediment water interface. The duration of data collection for each file was relatively short ( $\sim$ to $2 \mathrm{~min}$ ), and the order in which heights were used was randomized to minimize the effects of changing flow intensity during the tide cycle. Replicate measurements of velocity were collected at the beginning and end of the profile at the greatest height above the bottom in order to assess whether the tidal flow changed appreciably during data collection. In addition, between profiles we collected velocity data at a mid-water depth in order to obtain additional measures of bulk flow $\left(U_{\mathrm{b}}\right)$ over the various stages of the tide.

Velocity data were used to describe flow over the benthos and to calculate mean velocity for each of the components $\bar{U}, \bar{V}$, and $\bar{W}$ ). Estimates of the drag fric- tion coefficient $\left(c_{\mathrm{f}}\right)$ for the benthos were estimated using the equation $C_{\mathrm{f}}=2\left(u^{* 2} / U_{\mathrm{b}}{ }^{2}\right)$, where $u^{*}$ is the bottom shear velocity based on the commonly cited Karman-Prandtl equation:

$$
\bar{U}=u^{*} / k_{\mathrm{v}} \ln \left(Z / Z_{\mathrm{o}}\right)
$$

where $\bar{U}$ is the mean velocity at a given height $(Z)$ above the bottom and $k_{\mathrm{v}}$ is the von Karman constant. This method utilizes the portion of the profile in which velocity increases logarithmically with increasing height above the bottom. The roughness length $\left(Z_{\mathrm{o}}\right)$ was estimated as the intercept of the velocity versus ln $Z$ plot and is a measure of the roughness imposed by the benthos on the flowing water. Only those profiles that fit the equation with an $\mathrm{r}^{2}>0.90$ were retained for estimating $u^{*}$.

Predicting mass-transfer coefficients. Nutrient uptake by the benthos is dependent on the mass-transfer coefficient $(S)$ and the concentration of the nutrient in the water column. If the rate at which the benthos removes a nutrient from the water column exceeds the rate of delivery to the uptake surface, then $S$ will be dependent on the molecular diffusivity of the nutrient (D) and the thickness of the diffusive boundary layer

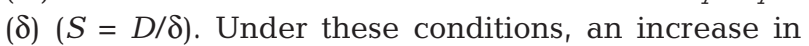
water velocity and/or roughness of the benthos will 
enhance turbulence and shear near uptake surfaces and thin diffusive boundary layers, in turn enhancing the mass-transfer coefficient.

Assuming that nutrient uptake by the benthic community on Old Sweat Bank is mass-transfer limited, values of $S$ can be predicted using semi-empirical mass-transfer models based traditionally on the calculation of a dimensionless Stanton (St) number $(\mathrm{St}=S$ $\mathrm{U}^{-1}$; see Bilger \& Atkinson 1992, Dade 1993, Thomas \& Atkinson 1997, Thomas et al. 2000). More recently, Falter et al. (2004) simplified original expressions used in calculating St into the following equation for predicting $S$ :

$$
S \approx \Gamma \frac{\sqrt{C_{\mathrm{f}} / 2}}{\operatorname{Re}^{*} 0.2 \mathrm{Sc}^{0.58}}
$$

where $C_{\mathrm{f}}$ is the drag friction coefficient as described above, $\mathrm{Re}^{*}$ is the Reynolds roughness number $\left(\mathrm{Re}^{*}=\right.$ $\left(u^{*}\right) Z_{\mathrm{o}} / v$, where $v$ is kinematic viscosity), and $\mathrm{Sc}$ is the Schmidt number of a specific dissolved nutrient $(\mathrm{Sc}=$ $v / D$ ). Values of $S$ are therefore dependent on water temperature, which in turn affects chemical diffusivity and viscosity. $\Gamma$ is an empirical constant $(0.46)$ derived from flume experiments involving low-relief corals (see Falter et al. 2004). This value was used in predicting $S$ for Old Sweat Bank and later compared to the value of $\Gamma$ derived as the slope of $S$ measured in flume experiments (see next section 'Validating predictions') versus the quotient term in Eq. (2) (see Falter et al. 2004).

Validating predictions. In order to test whether nutrient uptake by the benthos is mass-transfer limited and to validate predictions, values of $S$ based on rates of ammonium uptake by the benthos were measured in situ using a field flume. The modified race-track flume design and methods of deployment are explained in detail in previous studies (Thomas et al. 2000, Cornelisen \& Thomas 2004). Briefly, a total of 11 deployments were completed between 23 May and 7 June 2000 for measuring $S$ over a range of velocity consistent with natural tidal currents flowing over the bank $\left(U_{\mathrm{b}}=0.08\right.$ to $\left.0.38 \mathrm{~m} \mathrm{~s}^{-1}\right)$. For each deployment, the flume isolated $3.7 \mathrm{~m}^{2}$ of the benthos and a spike of $\mathrm{NH}_{4} \mathrm{Cl}$ added to the flume provided a beginning concentration of $\sim 6 \mu \mathrm{mol} \mathrm{l}^{-1}$ (on top of ambient concentrations typically between 0.2 and $0.5 \mu \mathrm{mol} \mathrm{l}^{-1}$ ). Each estimate of $S$ at a given velocity was based on the decline in $\mathrm{NH}_{4}{ }^{+}$concentration in the water column over a 45 to 60 min period (see Thomas et al. 2000 for methods of sample collection). A first-order rate constant ( $k$ ) was estimated as the slope of the natural log of concentration $(C)$ versus time $(t)$, where $C=-k \mathrm{~d} C / \mathrm{d} t$. Each firstorder rate constant $(k)$ was normalized for water volume in the flume (Vol) and planar surface area of the benthos enclosed by the flume $(A)$ to obtain a mea- sured mass-transfer coefficient $\left(S=k^{\mathrm{Vol}} / A\right)$. Measured values of $S$ were then compared to those predicted using the data from velocity profiles collected in the flume and Eqs. (1) and (2).

During the same time period, we conducted 14 additional flume experiments using ${ }^{15} \mathrm{~N}$-labeled ammonium (98 atomic $\%{ }^{15} \mathrm{NH}_{4}{ }^{+}$) in order to evaluate the effects of water flow on benthic and suspended organisms and to validate that uptake was occurring within the community components. These experiments were conducted in the same manner as those described in the preceding paragraph; however, they were shorter in duration ( $30 \mathrm{~min})$ and had a lower beginning concentration $\left(4 \mu \mathrm{mol} \mathrm{l}^{-1}\right)$. Experiments were conducted in pairs, with 1 completed at a low velocity $(0.05 \pm 0.01 \mathrm{~m}$ $\left.\mathrm{s}^{-1}\right)$ and 1 completed at a high velocity $(0.19 \pm 0.05 \mathrm{~m}$ $\mathrm{s}^{-1}$ ) on a given day. The order in which low- and highvelocity treatments were conducted each day was alternated.

Immediately upon completion of each experiment, composite samples (3 to 6 individual samples pooled) of common benthic components, including seagrass leaves (Thalassia testudinum and Syringodium filiforme), seagrass epiphytes, macroalgae (Laurencia papillosa, Halimeda monile, Penicillus capitatus), and finger coral (Porites sp. resembling forma divaricata), were haphazardly collected from the flume. In addition, a $1 \mathrm{l}$ bottle (Nalgene) was filled at mid-depth and filtered through a GF/F filter using a hand pump in order to obtain a sample of plankton on the filter (represented by particulate organic nitrogen [PON]). Detailed methods of processing seagrass leaves, epiphytes, and PON are provided in Cornelisen \& Thomas (2006). Macroalgae were processed in a similar manner as the seagrass leaves; subsamples of tissues from multiple thalli were pooled to represent the sample for a given flume deployment. Coral tissue was collected from coral colonies by placing scraped coral tissues on a pre-combusted glass fiber filter. Ambient samples of each of the components were analyzed to determine natural isotope abundances. Methods for analyzing samples and measuring uptake rates for individual community components are described in Cornelisen \& Thomas $(2004,2006)$.

Estimating nutrient uptake. Nutrient uptake by the benthos $\left(J\right.$ in $\left.\mu \mathrm{mol} \mathrm{NH} \mathrm{NH}_{4} \mathrm{~m}^{-2} \mathrm{~s}^{-1}\right)$ can be described using the commonly cited equation: $J=S\left(C_{\mathrm{b}}-C_{\mathrm{w}}\right)$ where $S$ is the mass-transfer coefficient (in units $\left.\mathrm{m} \mathrm{s}^{-1}\right)$ and $\left(C_{\mathrm{b}}-\right.$ $C_{\mathrm{w}}$ ) represents the gradient in nutrient concentration between the bulk fluid $\left(C_{\mathrm{b}}\right)$ and the wall of the organisms $\left(C_{\mathrm{w}}\right)$. When uptake is mass-transfer limited, this gradient is maximal ( $C_{\mathrm{w}}$ assumed to be 0 ) and uptake is equivalent to $S$ times the concentration in the bulk fluid $\left(C_{\mathrm{b}}\right)$. The uptake of a given nutrient by the benthic community over time was estimated by multiply- 
ing predicted values of $S\left(\mathrm{~m} \mathrm{~s}^{-1}\right)$ by the concentration of the nutrient in the bulk fluid (in $\mu \mathrm{mol} \mathrm{NH}_{4} \mathrm{~m}^{-3}$ ). During the field survey, $30 \mathrm{ml}$ water samples $(\mathrm{n}=43)$ were collected periodically (approx. every $30 \mathrm{~min}$ ) from the water column. Water samples were frozen at $-80^{\circ} \mathrm{C}$ until they were analyzed for ammonium concentrations using an autoanalyzer (Technicon) to within $\pm 0.05 \mu \mathrm{M}$. Ammonium concentrations were then multiplied by predicted values of $S$ over the range of current velocity observed at the study site in order to approximate rates of nutrient uptake occurring over the tidal cycle.

\section{RESULTS}

\section{Hydrodynamic characterization}

During collection of velocity data, signal-to-noise ratios were well above the recommended $15 \mathrm{db}$ level and the correlation values for the 3 sensors consistently ranged between 85 and $95 \%$. Water depth ranged between 0.39 and $0.99 \mathrm{~m}$ and deflected height of seagrass plants (for Thalassia testudinum and Syringodium filiforme combined) was between 0.10 and $0.16 \mathrm{~m}$; the overall length of the seagrass leaves ranged between 0.14 and $0.23 \mathrm{~m}$. Heights of other roughness elements (i.e. coral, algae, and sponges) were lower than the seagrass heights and ranged between 0.02 and $0.12 \mathrm{~m}$ (mean $\pm \mathrm{SD}=0.048 \pm$ $0.019 \mathrm{~m}, \mathrm{n}=53$ ).

Estimates of bulk flow $\left(U_{\mathrm{b}}\right)$ ranged between $0.03 \mathrm{~m}$ $\mathrm{s}^{-1}$ during brief slack tides and $0.39 \mathrm{~m} \mathrm{~s}^{-1}$ during flooding and ebbing tides. Typical vertical velocity profiles collected on the bank indicated that the current flowing over the benthos was highly unidirectional (Fig. 2). Although the community was colonized by seagrass, the level of flow attenuation within the canopy was much less than commonly observed in submerged vegetation. As an example, the profile collected in a densely colonized seagrass bed (560 shoots $\mathrm{m}^{-2}$ ) exhibited high flow attenuation within the base region of the canopy and resembled a mixing layer (see Ghisalberti \& Nepf 2002) rather than disturbed boundary layer flow as observed on the bank (Fig. 3). A higher level of turbulence was also observed within the top region of the dense seagrass canopy, which is illustrated by greater fluctuations in velocity (i.e. greater standard deviation).

Estimates of shear velocity $\left(u^{*}\right)$ ranged between 0.015 and $0.066 \mathrm{~m} \mathrm{~s}^{-1}$. Regressions for determining $u^{*}$ had a mean $\mathrm{r}^{2}$ of $0.96(\mathrm{SD}=0.03)$, confirming a good fit to Eq. (1). Roughness length $\left(Z_{\mathrm{o}}\right)$ ranged between 0.013 and $0.062 \mathrm{~m}$. Drag friction coefficients $\left(C_{\mathrm{f}}\right)$ for the mixed seagrass-coral assemblage ranged between 0.020 and 0.096 (mean $\pm \mathrm{SD}=0.062 \pm 0.023, \mathrm{n}=19)$, which is slightly higher than values for low-relief coral rubble (mean $=0.043$; Thomas \& Atkinson 1997) and considerably lower than the value estimated for the patch of dense seagrass (0.59). The $C_{\mathrm{f}}$ value for the dense seagrass fell within the range of previously published values for dense seagrass canopies (Thomas et al. 2000).

\section{Predicting mass-transfer coefficients}

For conditions during the collection of velocity profiles both in the field and during flume experiments,
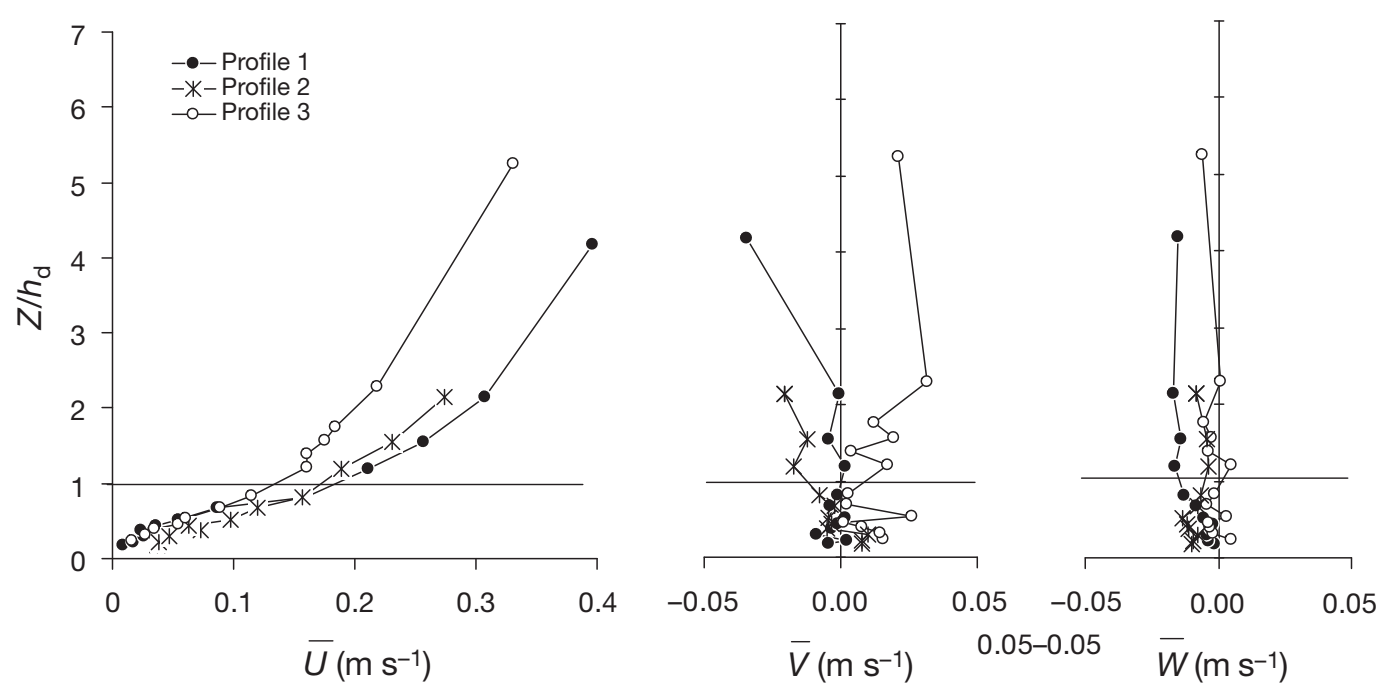

Fig. 2. Three typical vertical profiles of mean velocity in the longitudinal $(U)$, transverse $(V)$, and vertical $(W)$ directions for height above the bottom $(Z)$ normalized to deflected canopy height $\left(Z / h_{\mathrm{d}}, 1=\right.$ height of canopy) 


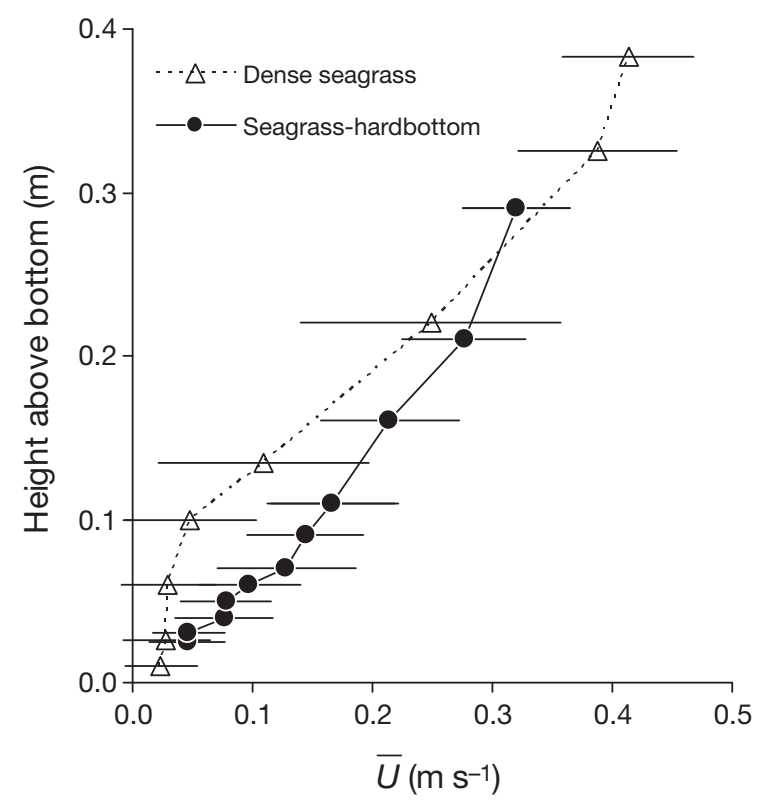

Fig. 3. Vertical profiles of mean longitudinal velocity $(\bar{U})$ for a profile collected in the mixed seagrass-hardbottom community and a profile collected in a nearby patch of dense seagrass under comparable current speeds. Error bars: \pm SD

predicted values of $S$ for ammonium expected under mass-transfer limitation ranged between $0.35 \times 10^{4}$ and $1.91 \times 10^{4} \mathrm{~m} \mathrm{~s}^{-1}$. Adequate velocity profiles were unable to be obtained near slack tide; however, profiles collected during the flume experiments at low velocities provided estimates of $S$ during periods of low flow. The regression (Model II) of $S$ versus bulk flow $\left(U_{\mathrm{b}}\right)$ for data collected under ambient conditions (outside the flume) pooled with those collected within the flume was $\left(3.8 \times 10^{-4}\right) U_{\mathrm{b}}{ }^{0.69} ;(\mathrm{p}<0.001, \mathrm{r}=0.89,95 \%$ $\mathrm{CI}=0.63$ to 0.76 ) (Fig. 4).

\section{Validating predictions}

For 10 of the flume deployments, regressions for determining first-order rate constants $(k)$ were significant $(p<0.05)$ with an average $r^{2}$ value of 0.86 (range $=$ 0.75 to 0.95 ). One experiment conducted at a velocity of $0.042 \mathrm{~m} \mathrm{~s}^{-1}$ resulted in a relatively poor relationship between concentration and time $\left(\mathrm{r}^{2}=0.62, \mathrm{p}=0.06\right)$. Measured mass-transfer coefficients $(S)$ ranged between $0.53 \times 10^{4}$ and $1.55 \times 10^{4} \mathrm{~m} \mathrm{~s}^{-1}$ and were significantly dependent on water velocity $\left(3.5 \times 10^{-4}\right)$ $U_{\mathrm{b}}^{0.66}$; $(\mathrm{p}<0.001, \mathrm{r}=0.79,95 \% \mathrm{CI}=0.50$ to 0.81$)$. The level of dependence of uptake rates on $U_{\mathrm{b}}$ were in close agreement with that expected for mass-transferlimited uptake (i.e. when uptake is proportional to current velocity to the 0.75 root; Hearn et al. 2001). Measured values of $S$ were generally in agreement with

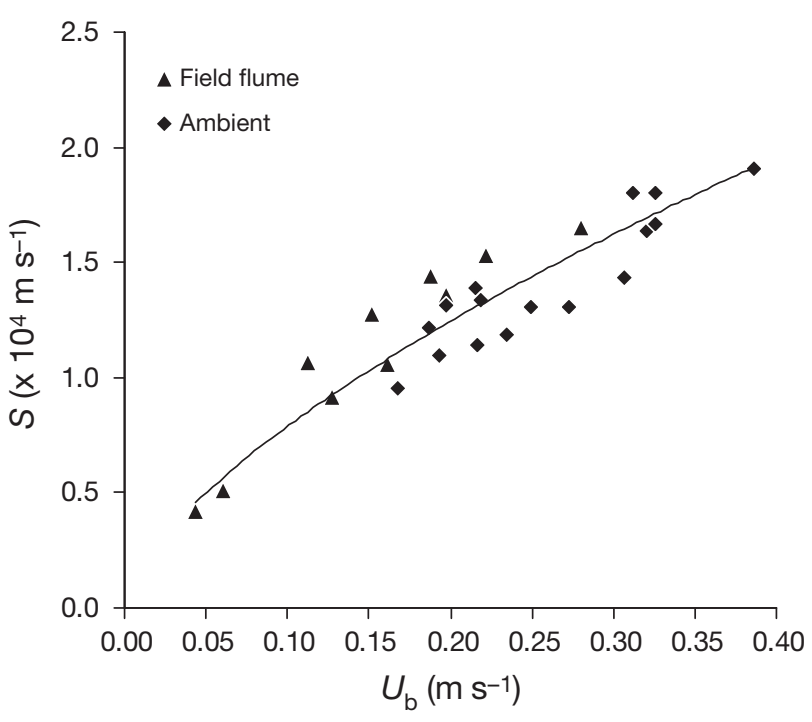

Fig. 4. Predicted mass-transfer coefficients $(S)$ versus depthaveraged velocity $\left(U_{\mathrm{b}}\right)$. Adequate $\mathrm{ADV}$ profiles were unobtainable near slack tide; therefore we include results based on profiles collected within the field flume, which provide estimates at the low range of $U_{\mathrm{b}}$. The line represents the regression of $S$ vs. bulk flow $\left(U_{\mathrm{b}}\right)$ using the pooled data $\left(3.8 \times 10^{-4}\right)$ $U_{\mathrm{b}}{ }^{0.69} ;(\mathrm{p}<0.001, \mathrm{r}=0.89,95 \% \mathrm{CI}=0.63$ to 0.76$)$

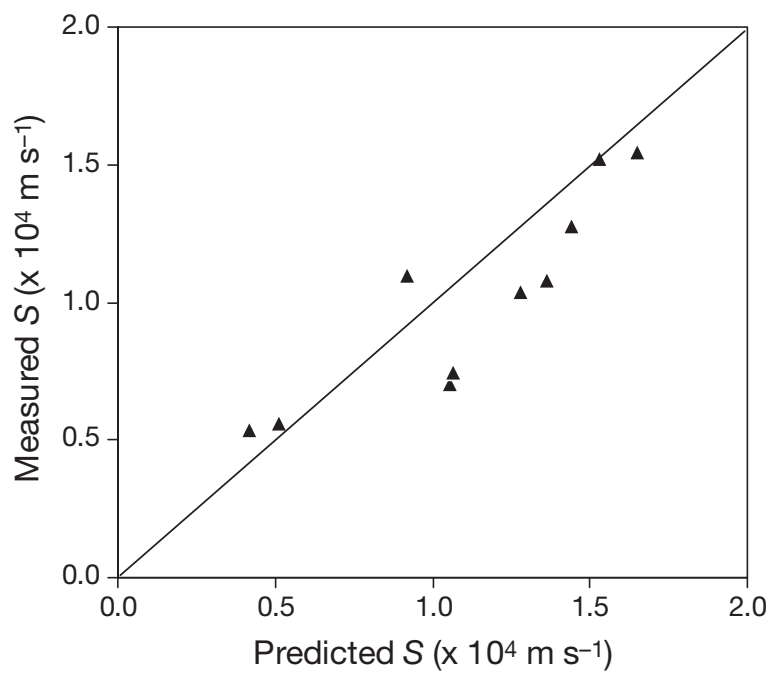

Fig. 5. Mass-transfer coefficients $(S)$ based on ammonium uptake rates measured in the field flume versus predicted values of $S$ using data from velocity profiles collected within the field flume during uptake experiments and Eq. (2). Solid line represents a 1:1 ratio

predicted values based on Eq. (2) (Fig. 5), although in a number of experiments, measured values were lower than those predicted. These results indicate that ammonium uptake by these communities is likely occurring near the mass-transfer limit; uptake rates 

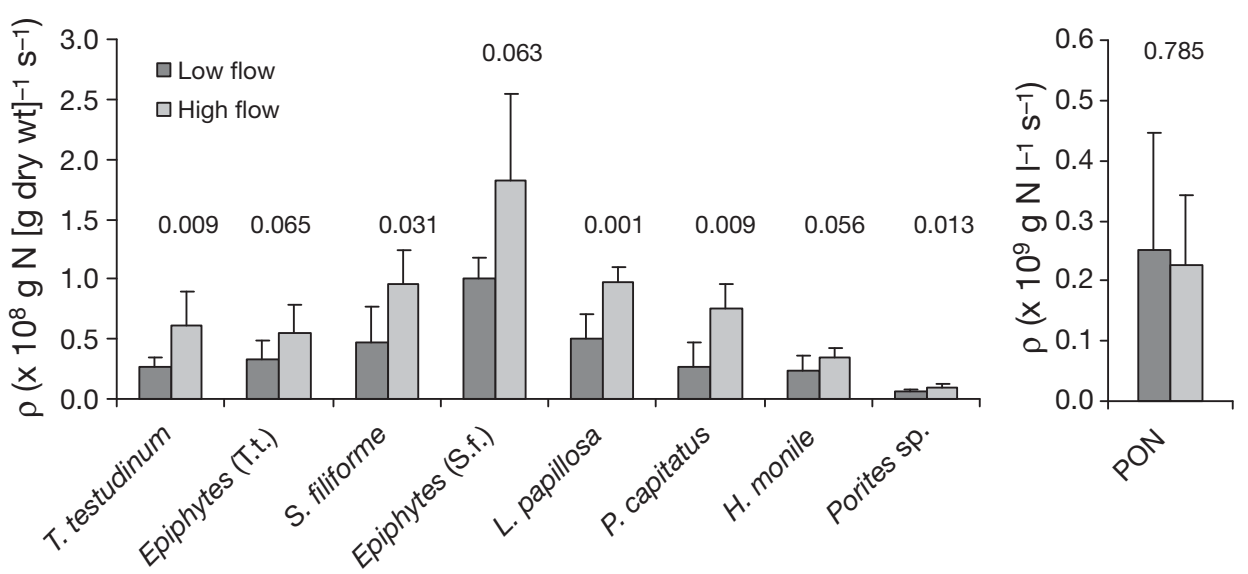

Fig. 6. Uptake rates (mean, SD) from a series of ${ }^{15} \mathrm{~N}$-labeled $\mathrm{NH}_{4}{ }^{+}$uptake experiments conducted at low $\left(0.05 \pm 0.01 \mathrm{~m} \mathrm{~s}{ }^{-1}\right)$ and high $\left(0.19 \pm 0.05 \mathrm{~m} \mathrm{~s}^{-1}\right)$ flow. The p-values from ANOVA are shown for Thalassia testudinum $(F=9.77, \mathrm{df}=13)$, epiphytes of $T$. testudinum $(F=4.10, \mathrm{df}=13)$, Syringodium filiforme $(F=6.79, \mathrm{df}=9)$, epiphytes of $S$. filiforme $(F=4.68$, df $=9)$, Halimeda monile $(F=4.47, \mathrm{df}=13)$, Laurencia papillosa $(F=22.87, \mathrm{df}=10)$, Penicillus capitatus $(F=11.88, \mathrm{df}=9)$, Porites sp. $(F=8.45, \mathrm{df}=13)$, and particulate organic nitrogen $\left(\mathrm{PON}_{i} F=0.078 \mathrm{df}=13\right.$ ) filtered from the water column. Some organisms were not always present during experiments

will therefore be driven by the ambient ammonium concentration and hydrodynamic regime. As hypothesized, measured values of $S$ for ammonium fell slightly above those previously measured for low-relief coral rubble $\left(0.16 \times 10^{4}\right.$ to $1.13 \times 10^{4} \mathrm{~m} \mathrm{~s}^{-1}$; Thomas \& Atkinson 1997) and below those for dense stands of Thalassia testudinum $\left(0.81 \times 10^{4}\right.$ to $2.21 \times 10^{4} \mathrm{~m} \mathrm{~s}^{-1}$; Thomas et al. 2000).

Results from the paired flume experiments using ${ }^{15} \mathrm{~N}$-labeled ammonium (98 atomic \% ${ }^{15} \mathrm{NH}_{4}{ }^{+}$) indicated that uptake by a range of common benthic organisms found in Florida Bay is affected by water flow (Fig. 6). Comparisons using ANOVA for low- and highflow treatments were statistically significant $(p<0.05)$ for all benthic components except for epiphytes attached to seagrass leaves and Halimeda monile, although in each of these latter cases, $p$-values were only slightly higher than 0.05 (see Fig. 6). On a per-gramtissue basis, seagrasses and the macroalgae Laurencia papillosa and Penicillus capitatus had similar uptake rates, as did the calcareous macroalgae $H$. monile and finger coral Porites sp. Uptake rates for epiphytes associated with the cylindrical-bladed Syringodium filiforme were up to 3 times higher than the uptake rates for epiphytes associated with the flat-bladed Thalassia testudinum. No effort was made to formally identify epiphytes, although field observations suggest that epiphytes on both species of seagrass were dominated by encrusting coralline algae and that $S$. filiforme leaves also had fine filamentous algae sparsely distributed along their surface. Contrary to benthic components, the particulate fraction suspended in the water column was not affected by water velocity (Fig. 6). Up- take in the water column represented on average $6.7 \%$ $(\mathrm{SD}=3.3 \%)$ of the total uptake during flume experiments. These results provide verification that a majority of the uptake occurred in the benthos and further evidence that uptake of ammonium by benthic components and the community as a whole was dependent on water flow.

\section{Predicting nutrient uptake}

Values of $S\left(\mathrm{~m} \mathrm{~s}^{-1}\right)$ multiplied by the concentration of the nutrient in the water column (in $\mu \mathrm{mol} \mathrm{NH}_{4} \mathrm{~m}^{-3}$ ) provide an estimate of uptake. As demonstrated in our experiments, values of $S$ for ammonium are dependent on current velocity and therefore will fluctuate over a tidal cycle as current velocity increases during ebbing and flooding tides and decreases during slack tide (Fig. 7a). During the field sampling period, ammonium concentrations also varied according to the tide; concentrations ranged from 0.16 to $0.55 \mu \mathrm{mol} \mathrm{l}^{-1}$ and increased as the tide dropped and water from Florida Bay progressed over the bank (Fig. 7b). Uptake of ammonium by the mixed seagrass-coral community on Old Sweat Bank, based on predicted values of $S$ over the range of $U_{\mathrm{b}}$ and ambient ammonium concentra-

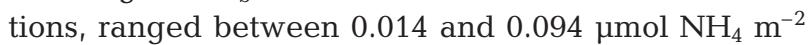
$\mathrm{s}^{-1}$ (Fig. $7 \mathrm{c}$ ). Due to the strong dependence of uptake on current speed, uptake was predicted to be lowest at slack high tide and highest during ebbing and flooding tide. Uptake rates were also enhanced during slack low tide in comparison to slack high tide due to elevated ammonium concentrations. 


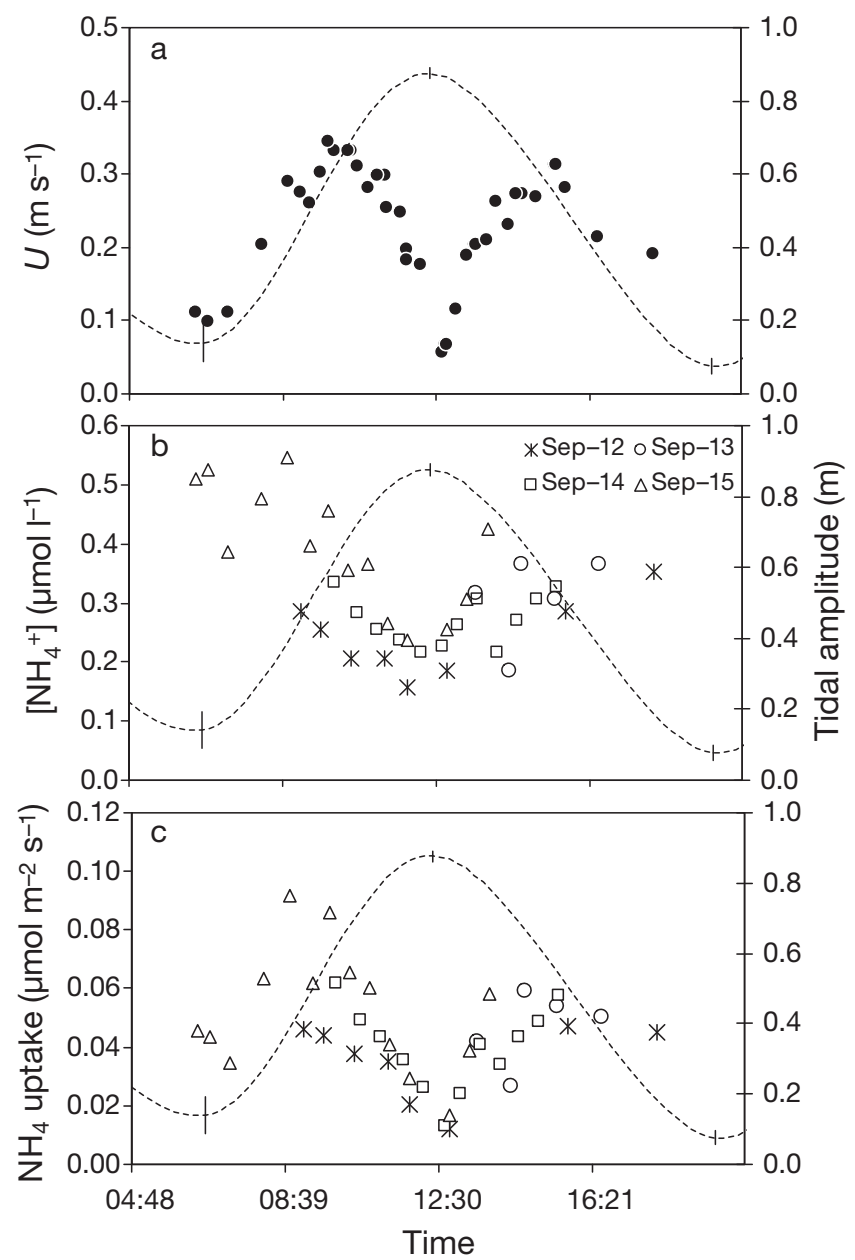

Fig. 7. (a) Mid-water velocity $(U)$, (b) water-column ammonium concentration, and (c) approximate rates of uptake by the benthos using the relationship from data in Fig. 4 to predict mass-transfer coefficients $(S)$ from velocity and then multiplying by ammonium concentrations over the sampling period. Data were arranged according to tide stage during the period of field sampling and overlaid with the average predicted tidal amplitude over the $4 \mathrm{~d}$ period with bars depicting the variation in tide heights among days

\section{DISCUSSION}

\section{Hydrodynamic characteristics}

The benthos on Old Sweat Bank includes seagrasses sparsely mixed among macroalgae, solitary colonies of ahermatypic corals, and sponges. The composition and patchiness of the benthic community resulted in hydrodynamic conditions that were different than those typically described for seagrass canopies (e.g. Gambi et al. 1990, Koch \& Gust 1999). The shape of velocity profiles collected on the sparsely vegetated bank was characteristic of disturbed boundary-layer flow, whereas the profile in a neighboring dense stand of seagrass illustrated greater flow attenuation at the base of the canopy and what has been previously described as a mixing layer (Raupach et al. 1996, Ghisalberti \& Nepf 2002).

Current velocity remained strong $\left(U_{\mathrm{b}} \sim 0.20\right.$ to $0.40 \mathrm{~m} \mathrm{~s}^{-1}$ ) during ebbing and flooding tides and slack tide lasted only a matter of minutes, which indicates that the benthos on the bank is almost always exposed to relatively high velocity and therefore high shear stresses. At comparable velocity $\left(U_{\mathrm{b}}\right)$, values of shear velocity $\left(u^{*}\right)$ were $\sim 50 \%$ lower than $u^{*}$ measured in dense stands of seagrass (Gambi et al. 1990). Similarly, drag friction coefficients $\left(C_{\mathrm{f}}\right)$ for the bank were an order of magnitude lower than those estimated for seagrass canopies (Thomas et al. 2000) and slightly higher than those estimated for low-relief coral rubble over a similar range of current speeds (Thomas \& Atkinson 1997). Estimates of $C_{\mathrm{f}}$ remained relatively constant over a range of velocity despite the presence of flexible seagrass leaves. In denser canopies of vegetation, the friction coefficient decreases with water velocity due to the bending of the canopy with increased flow (Thomas et al. 2000).

\section{Effects of water flow on uptake}

Predicted mass-transfer coefficients $(S)$ based on hydrodynamic data generally agreed with those obtained through direct measurement of ammonium uptake by the benthos, although predicted values tended to be slightly higher than those that were measured. This is partially due to the fact that we used an empirically derived constant of 0.46 in Eq. (2) that was based on flume experiments involving coral communities (see Falter et al. 2004). The community studied here included seagrass, which has been shown to display differences from coral assemblages in the relationship between velocity and frictional characteristics (Thomas et al. 2000). Based on our flume experiments, the value of this constant would be slightly lower (0.42) and would in turn slightly improve predictions of uptake for the mixed seagrass-hardbottom community.

The dependence of uptake on water velocity and the generally good agreement between measured and predicted values of $S$ provides strong evidence that ammonium uptake by the benthic community on Old Sweat Bank is occurring near the mass-transfer limit and therefore is largely controlled by hydrodynamics and nutrient concentration. Results from the ${ }^{15} \mathrm{~N}$ labeled ammonium experiments confirmed that ammonium uptake by benthic organisms that comprise the community, including macroalgae, corals, seagrass, and associated epiphytes was influenced by water velocity. Uptake rates varied considerably 
among the organisms. It is possible that some of these organisms did not exhibit mass-transfer-limited uptake (i.e. organisms were within a transition between physiological and physical limitation) despite the fact that the whole community was mass-transfer limited. Alternatively the organisms may have been mass-transfer limited and differences in uptake rates may have resulted from small-scale differences in their morphology or perhaps vertical location within the canopy. Despite a high level of variability in uptake rates among the different types of organisms, rates of uptake by the entire community (represented by values of $S$ ) remained within the range expected for mass-transferlimited uptake by the benthos as a whole.

Unlike the benthic components, the suspended particulate fraction was unaffected by water flow. In a previous study conducted in a protected bay, we found uptake by the suspended particulate fraction to increase with velocity (Cornelisen \& Thomas 2006). This was attributed to an increase in the actual amount of particulates in the water column as a function of resuspension rather than an influence of turbulence on uptake rates. Old Sweat Bank is regularly exposed to high currents and as a result the amount of material that is suspended during ebbing and flooding tides is likely minimal. Our data confirm this and indicate that the actual amount of material did not increase with velocity; therefore any unattached, suspended organisms actively removing ammonium were likely too small to benefit from increases in turbulence within the water column (e.g. Logan \& Dettmer 1990, Karp-Boss et al. 1996).

\section{Additional factors influencing uptake}

Results from the present study together with those from studies on seagrass and coral communities (e.g. Thomas \& Atkinson 1997, Thomas et al. 2000) demonstrate how a change in bottom roughness has a strong influence on turbulence near the benthos and in turn on rates of mass transfer. As hypothesized, mass-transfer coefficients for the community on Old Sweat Bank over a comparable range of flow velocity fell slightly above those measured for low-relief coral rubble (Thomas \& Atkinson 1997) and below those measured in a uniform Thalassia testudinum canopy (Thomas et al. 2000). In the absence of any physical data, this could be interpreted to be a function of differences in abundances and nutrient physiology between organisms forming the communities. Evidence from all of these studies, however, suggests that nutrient uptake was a physically limited process; measured masstransfer coefficients were in close agreement with those predicted using measures of bottom roughness and water flow.
The above results collectively suggest that a shift in organisms comprising a benthic community and a subsequent change in 'roughness' would in turn alter nutrient uptake rates for the community. For instance, if the community on Old Sweat Bank was to be replaced by a uniform Thalassia testudinum bed, rates of ammonium uptake would nearly double due to the substantial increase in friction and turbulent energy. Alternatively, a reduction in uptake would occur with a loss of seagrass and conversion of the benthic community to low-relief corals, which results in lower bottom friction and in turn slightly lower uptake rates than the community on Old Sweat Bank. These changes are dependent on the assumption that the community is comprised of organisms that assimilate dissolved nutrients and that uptake of a given nutrient is a physically limited process. As demonstrated in Cornelisen \& Thomas (2006), the extent to which nutrient uptake is biologically or physically limited can depend on the nitrogen species (e.g. nitrate vs. ammonium) and potentially varies in time depending on nutrient history and the physiological status of the organisms forming the community (e.g. Sanford \& Crawford 2000).

An important consideration is that the experiments conducted in the present study and other mass-transfer studies have been conducted during daylight hours and that organism physiology or perhaps increased nutrient efflux from sediments may play a larger role during dark periods. Seagrasses have shown similar rates of nutrient uptake during day and night hours (Lee \& Dunton 1999, Touchette \& Burkholder 2000); however, further research is required to investigate the extent to which mass-transfer models hold true for the community as a whole over a $24 \mathrm{~h}$ period. Applications of isotope labels in night experiments would also assist in identifying and understanding diurnal patterns in nutrient uptake at the organism level.

Field measurements of water velocity $\left(U_{\mathrm{b}}\right)$ and water-column ammonium concentration varied in time as a function of the tide. As a result, the lowest uptake was predicted to occur at slack high tide when velocity and concentration was also lowest. Uptake was predicted to be highest during slack low tide (when ammonium concentration was highest) and during ebbing and flooding tides (when current velocity was highest). These results demonstrate how both hydrodynamic regime and the nutrient concentration within the water column can have similar magnitudes of influence on ammonium uptake rates for the benthos. In addition to hydrodynamics and nutrient concentration, uptake of a nutrient will be dependent on water temperature due to its influence on molecular diffusivity $(D)$ and kinematic viscosity $(v)$. The community on Old Sweat Bank is exposed to a temperature range of 
approximately $10^{\circ} \mathrm{C}$ throughout the year $\left(\sim 22^{\circ} \mathrm{C}\right.$ in winter and $32^{\circ} \mathrm{C}$ in summer). Based on this temperature range, it is estimated that the uptake of ammonium at an equivalent velocity and nutrient concentration will increase up to $15 \%$ during the summer in comparison to the winter simply due to an increase in diffusivity and decrease in viscosity. Field work was conducted during low wind and calm surface water conditions; hence tides were the primary driver of hydrodynamic conditions. As suggested by Hearn et al. (2001) and demonstrated by Thomas \& Cornelisen (2003), the presence of waves would likely further enhance uptake by the benthos on the order of $25 \%$; however, this enhancement would be relatively minor compared to that driven by the large range of mean flow over a tide cycle (Falter et al. 2005).

In summary, our results indicate that rates of ammonium uptake for the benthic assemblage on Old Sweat Bank are mass-transfer limited during daylight hours. Therefore, the rate at which the assemblage is removing ammonium from the water column is controlled by the ammonium concentration and hydrodynamic conditions, which in turn are influenced by tidal currents and morphological characteristics of the benthos. It has been widely accepted that primary production in carbonate environments such as Florida Bay is largely phosphorus-limited, which in turn suggests that uptake of dissolved forms of nitrogen in such environments shouldn't necessarily be physically limited (i.e. dissolved inorganic nitrogen [DIN] pools would be full). However, N:P ratios are relatively balanced in the vicinity of Old Sweat Bank (Fourqurean \& Zieman 2002), suggesting that both $N$ and $P$ uptake will be mass-transfer limited in this area. Future experiments investigating uptake of phosphate as well as other DIN forms (e.g. nitrate) would assist in understanding the factors driving assimilative capacity of the benthos in Florida Bay, a region that demonstrates high temporal and spatial variability in nutrient inputs and patterns of nitrogen and phosphorus limitation.

Acknowledgments. We thank the numerous individuals who contributed to fieldwork, including N. Craig, M. Driscoll, S. Kinane, T. Bolton, N. Smiley, and J. Kapp. We thank IsoAnalytical Ltd. and K. Fanning's laboratory and staff for assistance with sample analysis as well as the staff at the Keys Marine Laboratory on Long Key. This research represents a portion of C.D.C.'s doctoral research at the University of South Florida and was funded by a National Science Foundation PECASE award and Grant to F.I.M.T. (OCE-9996361, OCE-0715417). This is HIMB contribution \# 1350.

\section{LITERATURE CITED}

Atkinson MJ, Falter JL, Hearn CJ (2001) Nutrient dynamics in the Biosphere 2 coral reef mesocosm: water velocity con- trols $\mathrm{NH}_{4}$ and $\mathrm{PO}_{4}$ uptake. Coral Reefs 20:341-346

Baird M, Atkinson MJ (1997) Measurement and prediction of mass transfer to coral reefs. Limnol Oceanogr 42: 1685-1693

Baird ME, Roughan M, Brander RW, Middleton JH, Nippard GJ (2004) Mass-transfer-limited nitrate uptake on a coral reef flat, Warraber Island, Torres Strait, Australia. Coral Reefs 23:386-396

Bilger RW, Atkinson MJ (1992) Anomalous mass transfer of phosphate on coral reef flats. Limnol Oceanogr 37: 261-272

Boudreau BP, Scott MR (1978) A model for the diffusioncontrolled growth of deep-sea manganese nodules. Am J Sci 278:903-929

Cornelisen CD, Thomas FIM (2004) Ammonium and nitrate uptake by leaves of the seagrass Thalassia testudinum: impact of hydrodynamic regime and epiphyte cover on uptake rates. J Mar Syst 49:177-194

Cornelisen CD, Thomas FIM (2006) Water flow enhances ammonium and nitrate uptake in a seagrass community. Mar Ecol Prog Ser 312:1-13

Dade WB (1993) Near-bed turbulence and hydrodynamic control of diffusional mass transfer at the sea floor. Limnol Oceanogr 38:52-69

Falter JL, Atkinson MJ, Merrifield MA (2004) Mass-transfer limitation of nutrient uptake by a wave-dominated reef flat community. Limnol Oceanogr 49:1820-1831

Falter JL, Atkinson MJ, Coimbra CFM (2005) Effects of surface roughness and oscillatory flow on the dissolution of plaster forms: evidence for nutrient mass transfer to coral reef communities. Limnol Oceanogr 50:246-254

FMRI (Florida Marine Research Institute) (1998) Benthic habitats of the Florida Keys. Florida Department of Environmental Protection, St. Petersburg, FL

Fourqurean JW, Zieman JC (2002) Nutrient content of the seagrass Thalassia testudinum reveals regional patterns of relative availability of nitrogen and phosphorus in the Florida Keys USA. Biogeochemistry 61:229-245

> Gambi MC, Nowell ARM, Jumars PA (1990) Flume observations on flow dynamics in Zostera marina (eelgrass) beds. Mar Ecol Prog Ser 61:159-169

Ghisalberti M, Nepf HM (2002) Mixing layers and coherent structures in vegetated aquatic flows. J Geophys Res Oceans 107:3011

> Hearn CJ, Atkinson MJ, Falter JL (2001) A physical derivation of nutrient-uptake rates in coral reefs: effects of roughness and waves. Coral Reefs 20:347-356

> Jorgensen BB, Des Marais DJ (1990) The diffusive boundary layer of sediments: oxygen microgradients over a microbial mat. Limnol Oceanogr 35:1343-1355

Karp-Boss L, Boss E, Jumars PA (1996) Nutrient fluxes to planktonic osmotrophs in the presence of fluid motion. Oceanogr Mar Biol Annu Rev 34:71-107

> Koch EW, Gust G (1999) Water flow in tide- and wavedominated beds of the seagrass Thalassia testudinum. Mar Ecol Prog Ser 184:63-72

Lee KS, Dunton KH (1999) Inorganic nitrogen acquisition in the seagrass Thalassia testudinum: development of a whole-plant budget. Limnol Oceanogr 44:1204-1215

Logan BE, Dettmer JW (1990) Increased mass transfer to microorganisms with fluid motion. Biotechnol Bioeng 35: 1135-1144

Morris EP, Peralta G, Brun FG, van Duren L, Bouma TJ, Perez-Llorens JL (2008) Interaction between hydrodynamics and seagrass canopy structure: spatially explicit effects on ammonium uptake rates. Limnol Oceanogr 53: $1531-1539$ 
Raupach MR, Finnigan JJ, Brunet Y (1996) Coherent eddies and turbulence in vegetation canopies: the mixing layer analogy. Boundary-Layer Meteorol 78:351-382

Riber HH, Wetzel RG (1987) Boundary-layer and internal diffusion effects on phosphorus fluxes in lake periphyton. Limnol Oceanogr 32:1181-1194

Sanford LP, Crawford SM (2000) Mass transfer versus kinetic control of uptake across solid-water boundaries. Limnol Oceanogr 45:1180-1186

Thomas FIM, Atkinson MJ (1997) Ammonium uptake by coral reefs: effects of water velocity and surface roughness on mass transfer. Limnol Oceanogr 42:81-88

Editorial responsibility: Kenneth Heck Jr.,

Dauphin Island, Alabama, USA
Thomas FIM, Cornelisen CD (2003) Ammonium uptake by seagrass communities: effects of oscillatory versus unidirectional flow. Mar Ecol Prog Ser 247:51-57

Thomas FIM, Cornelisen CD, Zande JM (2000) Effects of water velocity and canopy morphology on ammonium uptake by seagrass communities. Ecology 81: 2704-2713

Touchette BW, Burkholder JM (2000) Review of nitrogen and phosphorus metabolism in seagrasses. J Exp Mar Biol Ecol 250:133-167

Wang JD (1998) Subtidal flow patterns in Western Florida Bay. Estuar Coast Shelf Sci 46:901-915

Submitted: October 8, 2008; Accepted: April 16, 2009

Proofs received from author(s): June 18, 2009 